\title{
PENGAWASAN TERHADAP KEWAJIBAN PEMBERIAN NAFKAH OLEH MANTAN SUAMI KEPADA MANTAN ISTRI PASCA PERCERAIAN
}

\author{
Ni Wayan Sintia Darma Putri, Fakultas Hukum Universitas Udayana, e-mail: \\ sintiadarmaputri00@gmail.com \\ Marwanto, Fakultas Hukum Universitas Udayana, e-mail: \\ marwanto@unud.ac.id
}

doi: https://doi.org/10.24843/KS.2020.v08.i10.p10

\begin{abstract}
ABSTRAK
Artikel ini bertujuan untuk mengetahui pengaturan terkait dengan instansi yang berwenang mengawasi pemberian nafkah oleh mantan suami setelah diputus cerai. Metode penelitian normatif digunakan pada penelitian ini melalui pendekatan perundang-undangan serta pendekatan analitis. Hasil penelitian menunjukan bahwa tidak adanya instansi yang mengawasi jalannya mantan suami memberi nafkah kepada mantan istri setelah diputus cerai menyebabkan suami bertindak lalai dan tidak melaksanakan kewajibannya sebagaimana putusan pengadilan. Tindakan ini menunjukan bahwa adanya ketidakpastian hukum yang menyebabkan kerugian materiil bagi mantan istri sehingga hukum tidak mencapai tujuannya sebagaimana hukum harus menjamin adanya keadilan bagi para pihak yang tentunya dapat bermanfaat bagi masyarakat.
\end{abstract}

Kata Kunci: Pengawasan, Kewajiban Pemberian Nafkah, Perceraian

\begin{abstract}
This article has the objective to find out arrangements relating to agencies that have the right to oversee the provision of income by ex-husband after the divorced is terminated. Normative research are used in this study through statute approach and analytical approach. The result of the study showed that the absence of an agency that oversees the ex-husband way of providing income to the ex-wife after the divorced terminated caused the husband to act negligently and not carry out his obligations as a court ruling. This actions shows that there is legal uncertainty that causes material loss for ex-wife so that the law does not achieve its objectives as the law must ensure justice for the parties which certainly can benefit the community.
\end{abstract}

Key Words: Supervision, Obligation to provide a living, Divorce.

\section{Pendahuluan}

1.1 Latar Belakang

Perkawinan adalah suatu ikatan lahir batin antara dua manusia yang berlainan jenis kelamin untuk membangun sebuah keluarga serta meneruskan keturunan. ${ }^{1}$ Perkawinan harus dilaksanakan berdasarkan kepercayaan serta agama yang dianut. Menurut Wirjono Prodjodikoro yaitu seorang perempuan dan laki-laki yang menjalani kehidupan bersama-sama dengan melengkapi persyaratan tertentu serta apabila

1 Santoso, "Hakekat Perkawinan Menurut Undang-Undang Perkawinan, Hukum Islam Dan Hukum Adat." Yudisia: Jurnal Pemikiran Hukum Dan Hukum Islam 7, No. 2 (2016): 412-434. 
diteliti lebih dalam sebenarnya perkawinan merupakan sebuah perjanjian yang didasarkan dengan iman untuk mengikat secara lahir dan bathin. ${ }^{2}$ Setiap orang pasti mendambakan perkawinan yang berbahagia, harmonis dan langgeng sampai maut memisahkan namun tak jarang perkawinan berujung perceraian yang diakibatkan oleh ketidakcocokan saat menjalankan kehidupan berumah tangga, faktor orang tua dari kedua belah pihak, faktor ekonomi, hingga tindakan kekerasan didalam berumah tangga maupun pihak ketiga seperti mempunyai wanita idaman lain atau laki-laki idaman lain menyebabkan putusnya ikatan perkawinan.

Berdasarkan Undang-Undang Perkawinan putusnya ikatan perkawinan dikarenakan oleh adanya kematian, perceraian serta berdasarkan putusan pengadilan. Perceraian yang diakibatkan oleh putusnya perkawinan hanya dapat dilakukan oleh hakim dihadapan sidang pengadilan. Hal ini dilakukan sebagai tahap akhir setelah tahap untuk memediasi gagal sebagaimana amanat Pasal 31 ayat (1) Undang-Undang No. 16 Tahun 2019 Tentang Perubahan Atas Undang-Undang No. 1 Tahun 1974 Tentang Perkawinan (selanjutnya disebut UU Perkawinan).

Agar perceraian tersebut bisa terlaksana tentunya harus memberikan alasan yang cukup kuat untuk mengakhiri suatu hubungan perkawinan salah satunya yaitu pihak suami maupun pihak istri tidak dapat hidup rukun lagi untuk membina ikatan perkawinan. Tidak jarang yang menjadi korbannya adalah anak-anak hasil dari perkawinan tersebut. Putusnya ikatan perkawinan mengakibatkan terbaginya kasih sayang kepada anak. Putusnya ikatan perkawinan juga tidak menimbulkan menghilangnya kewajiban orang tua dalam hal untuk tetap memberikan nafkah kepada anak hingga anak tersebut cukup umur atau dapat menghidupi dirinya sendiri. ${ }^{3}$ Pengadilan yang memutus perceraian akan memutuskan anak dari hasil perkawinan ikut dengan pihak bapak atau pihak ibu.

Putusnya ikatan perkawinan ini atau biasa disebut dengan perceraian menimbulkan berbagai permasalahan baru seperti pembagian harta gono gini. Harta gono gini adalah harta yang didapat pada saat suami dan istri mulai berumah tangga hingga diputus cerai oleh pengadilan. ${ }^{4}$ Harta gono gini bagi sebagian orang sering disebut dengan istilah harta bersama sebagaimana ketentuan Pasal 35 ayat (1) UU Perkawinan. Perceraian juga akan sangat membebani perempuan karena kebanyakan dari perempuan yang membina rumah tangga akan mengorbankan karir mereka untuk membesarkan anak-anaknya yaitu untuk menjadi ibu rumah tangga sedangkan suami mencari nafkah sebagaimana amanat dari Pasal 31 ayat (3) UU Perkawinan.

Salah satu permasalahan yang membebani perempuan setelah bercerai adalah biaya untuk menafkahi dirinya dan anak dari hasil perkawinannya sehingga pada saat mengajukan gugatan perceraian perempuan akan menuntut kepada mantan suaminya untuk membiayai penghidupannya atau menuntut suatu kewajiban kepada mantan suami sebagaimana amanat dari Pasal 41 huruf c UU Perkawinan. Namun tak jarang mantan suami mengabaikan ketentuan ini yang jelas-jelas sudah di putus oleh pengadilan untuk melaksanakannya dan kalaupun ada yang melaksanakannya hanya

2 Erwinsyahbhana, Tengku. "Sistem Hukum Perkawinan Pada Negara Hukum Berdasarkan Pancasila." Jurnal Ilmu Hukum 3, No. 1 (2012): 1-29. DOI: http://dx.doi.org/10.30652/jih.v3i01.1027.

3 Zainuddin \& Zainuddin, Afwan. Kepastian Hukum Perkawinan Siri dan Permasalahannya Ditinjau dari Undang-Undang Nomor 1 Tahun 1974. Cet. I. (Yogyakarta, Deepublish, 2017), 29.

4 Yunani, Elti. Pelaksanaan Pembagian Harta Bersama (Gono Gini) Dalam Praktek Di Pengadilan Agama Bandar Lampung. (Tesis, Universitas Diponegoro, 2009), 102. 
sebagian dari putusan hakim saja yang dipenuhi. Padahal biaya untuk membesarkan anak sangat besar. Sehingga akhirnya mantan istrilah yang turun tangan untuk membanting tulang demi membiayai kebutuhannya dan anaknya. Seharusnya hak anak untuk mendapatkan pembiayaan hidup terjamin dalam ketentuan Pasal 28B ayat (2) UUD 1945 yang mengamanatkan selama anak hidup, bertumbuh dan berkembang, anak memiliki hak untuk dilindungi dari diskriminasi dan kekerasan terhadapnya yang seharusnya diberikan oleh kedua orang tuanya.

Sebelumnya telah ada penelitian sejenis yang mengkaji mengenai perceraian, yaitu pada Jurnal Kertha Semaya Fakultas Hukum Universitas Udayana dengan judul "Analisis Yuridis Terhadap Pendamaian Dalam Perkara Perceraian Aparatur Sipil Negara Dengan Pendekatan Hukum Perkawinan" yang ditulis oleh Brody Made Kariarta dan I Wayan Novy Purwanto. ${ }^{5}$ Penelitian lainnya berjudul "Akibat Hukum Pembatalan Hibah Istri Terhadap Suami Setelah Adanya Perceraian (Analisis Kasus: Putusan Mahakamah Agung Nomor 1893 K/Pdt/2015)" ditulis oleh Julian Albert Dewantara, I Made Sarjana dan I Nyoman Darmadha. ${ }^{6}$ Perbedaan penelitian ini dengan penelitian sebelumnya adalah dalam penulisan jurnal ilmiah ini permasalahan yang dikaji adalah mengenai bagaimanakah pengaturan terkait dengan instansi yang berhak mengawasi pemberian biaya penghidupan kepada mantan istri setelah diputus cerai oleh pengadilan dan bagaimanakah akibat yang ditimbulkan dengan tidak adanya instansi yang bertugas untuk mengawasi pemberian biaya penghidupan kepada mantan istri oleh mantan suami setelah diputus cerai. Berdasarkan pada latar belakang yang telah diuraikan diatas, maka menarik untuk dikaji secara lebih mendalam mengenai pengawasan kewajiban pemberian nafkah oleh mantan suami kepada mantan istri pasca perceraian.

\subsection{Rumusan Masalah}

Berdasarkan pemaparan latar belakang tersebut dapat diuraikan permasalahan yaitu:

1. Bagaimanakah pengaturan hukum terkait dengan instansi yang berwenang melakukan pengawasan terhadap kewajiban pemberian nafkah oleh mantan suami kepada mantan istri pasca perceraian?

2. Bagaimanakah akibat yang ditimbulkan dengan tidak adanya instansi yang berwenang untuk melakukan pengawasan terhadap kewajiban pemberian nafkah oleh mantan suami kepada mantan istri pasca perceraian?

\subsection{Tujuan Penelitian}

Penelitian ini bertujuan untuk mengetahui pengaturan terkait dengan instansi yang berhak mengawasi pelaksanaan mantan suami memberikan biaya penghidupan kepada mantan istri setelah diputus cerai oleh pengadilan serta mengetahui akibat yang ditimbulkan dengan tidak adanya instansi yang bertugas untuk mengawasi pemberian biaya penghidupan kepada mantan istri setelah diputus cerai.

5 Karirarta, Brody Made dan Purwanto, I Wayan Novy, "Analisis Yuridis Terhadap Pendamaian Dalam Perkara Perceraian Aparatur Sipil Negara Dengan Pendekatan Hukum Perkawinan", Kertha Semaya: Journal Ilmu Hukum 5 No. 1 (2017): 1-17.

6 Dewantara, Julian Robert, Sarjana, I Made, dan Darmadha, I Nyoman, "Akibat Hukum Pembatalan Hibah Istri Terhadap Suami Setelah Adanya Perceraian (Analisis Kasus: Putusan Mahakamah Agung Nomor 1893 K/Pdt/2015)" Kertha Semaya: Journal Ilmu Hukum 7 No.5 (2019): 1-13. 


\section{Metode Penelitian}

Jenis penelitian hukum dapat diklasifikasikan menjadi dua metode yaitu metode penelitian hukum normatif dan metode penelitian hukum empiris. Metode penelitian yang bidang kajiannya berupa hukum kemudian menjadikan norma tersebut sebagai objek penelitiannya, bertugas untuk membentuk norma atau ketentuan-ketentuan hukum namun tidak semata-mata hanya mendeskripsikan atau menjelaskan norma hukum disebut dengan penelitian hukum normatif. 7 Metode yang digunakan dalam penelitian ini adalah metode penelitian hukum normatif. Penelitian ini menjadikan norma sebagai objek penelitiannya karena beranjak dari adanya kekosongan norma terkait dengan tidak adanya peraturan yang mengatur suatu lembaga untuk mengawasi jalannya pemberian nafkah dari mantan suami kepada mantan istri setelah bercerai. Penelitian ini menggunakan pendekatan perundang-undangan (statute approach). Pendekatan perundang-undangan yang digunakan pada penelitian ini digunakan untuk menganalisa isu-isu hukum yang berkaitan dengan peraturan yang mengatur adanya instansi yang berhak mengawasi jalannya pelaksanaan pemberian nafkah dari mantan suami kepada mantan istri setelah diputus cerai.

\section{Hasil dan Pembahasan}

3.1 Pengaturan Tentang Instansi Yang Berhak Mengawasi Mantan Suami Memberikan Biaya Penghidupan Kepada Mantan Istri Setelah Diputus Cerai

Kewajiban pemberian nafkah setelah terjadi perceraian kepada mantan istri secara tegas diatur dalam ketentuan Pasal 41 huruf c UU Perkawinan, yang mengamanatkan terjadinya perceraian yang diakibatkan oleh putusnya perkawinan mengakibatkan memberikan kewajiban bagi mantan suami untuk menanggung biaya hidup dan/atau mewajibkan menetapkan suatu hal untuk mantan istri. Sehingga putusan pengadilan sangat berpengaruh untuk mewajibkan mantan suami memberi nafkah terhadap mantan istri. Bagi PNS putusan pengadilan untuk menentukan besaran tunjangan yang akan diberikan untuk mantan istri serta anaknya lebih lanjut diatur dalam ketentuan Pasal 8 PP No. 10/1983 yang menyatakan bahwa, jika PNS laki-laki berkehendak untuk melakukan perceraian terhadap istrinya maka PNS lakilaki tersebut berkewajiban untuk menyerahkan sebagian penghasilan bulanannya untuk menghidupi mantan istri beserta anak-anakya. Pembagian penghasilan bulanan ini dibagi sepertiga untuk mantan istrinya serta sepertiga untuk anak dari hasil perkawinannya. Namun jika tidak memiliki anak dalam ikatan perkawinan tersebut maka pembagian penghasilan bulanan yang diberikan wajib untuk mantan istri tersebut itu harus setengah dari penghasilan bulanannya.

KHI dalam ketentuan Pasal 165 huruf d mengatur mengenai akibat perceraian yang menyatakan bahwa, sesuai kemampuannya ayah memiliki tanggung jawab untuk menanggung seluruh biaya hadhanah serta nafkah terhadap anaknya hingga anak tersebut cukup umur dan mandiri atau berumur 21 tahun. Dalam KHI Hadhanah adalah memelihara dan mendidik anak yang belum dewasa. Apabila mantan suami lalai untuk memenuhi kewajibannya maka mantan suami akan dikenakan sanksi berat sebagaimana menurut ketentuan PP No. 10/1983 Pasal 16 yang menentukan bahwa

7 Diantha, I Made Pasek. Metodologi Penelitian Hukum Normatif Dalam Justifikasi Teori Hukum. Cet. II. (Jakarta, Prenadamedia Group, 2012), 85. 
mantan suami akan diberhentikan secara hormat tidak atas permintaannya sendiri sebagai PNS sebagai konsekuensi sanksi hukuman disiplin yang dijatuhkan padanya.

Namun jika mantan suami telah diwajibkan untuk menafkahi mantan istri oleh pengadilan tetapi menolak maka tindakan yang dilakukan oleh mantan suami ini merupakan tindakan pembangkangan terhadap putusan pengadilan sehingga berdasarkan ketentuan Pasal 196 HIR mengamanatkan apabila pihak mantan suami tidak berkenan atau lalai untuk menjalankan isi dari putusan pengadilan maka pihak mantan istri berhak untuk mengajukan permohonan dengan cara tertulis atau lisan kepada ketua PN yang disebutkan dalam Pasal 195 ayat (1), untuk menjalankan keputusan tersebut maka ketua pengadilan akan memanggil pihak mantan suami serta memperingatkannya agar pihak mantan suami memenuhi isi dari keputusan tersebut dengan tempo waktu yang telah diputuskan oleh ketua pengadilan selambatlambatnya delapan hari. Peraturan ini jelas mengatur mengenai cara yang dapat ditempuh oleh mantan istri jika mantan suami lalai melaksanakan kewajibannya.

Apabila mantan suami lalai untuk melaksanakan kewajibannya melewati batas waktu yang telah ditentukan diatas sehingga berdasarkan ketentuan Pasal 197 ayat (1) HIR mantan suami akan dipanggil secara patut, namun jika mantan suami tidak mau datang menghadap maka ketua pengadilan akan memberikan surat yang berisi perintah agar seluruh harta baik benda bergerak dan benda tidak bergerak disita tetapi apabila tidak ada atau dirasa kurang cukup maka akan disita lagi sekian banyak barang milik dari mantan suami hingga dirasa cukup untuk mengganti sejumlah uang yang disebutkan dalam putusan untuk meberikan nafkah kepada mantan istri serta ditambah dengan biaya untuk menjalankan putusan tersebut.

Adanya kelalaian mantan suami ini tidak terlepas oleh tidak adanya pengawasan dari lembaga atau instansi yang seharusnya ditugaskan untuk mengawasi pihak mantan suami memenuhi kewajibannya. UU Perkawinan hanya mencatumkan akibat dari putusnya perkawinan yaitu untuk mewajibkan mantan suami untuk bertanggungjawab menafkahi mantan istri yang telah diputus cerai tanpa adanya pemberian sanksi atau menunjuk suatu instansi untuk mengawasi jalannya pemberian nafkah terkait jika timbul kelalaian terhadap pemenuhan kewajiban oleh mantan suami kepada mantan istri. Kemudian dalam PP No. 9/1975 hanya mengatur mengenai pelaksanaan tata cara percerain tanpa lebih lanjut mengatur mengenai instansi yang berhak mengawasi mantan suami memberi nafkah kepada mantan istrinya yang telah diputus cerai dalam sidang pengadilan.

Berhasil atau tidaknya suatu hukum diterapkan tidak lepas dari adanya tiga unsur pembentuk sistem hukum sebagaimana yang dicetuskan oleh Lawrence $\mathrm{M}$. Friedmann yang mengatakan pembentuk sistem hukum terdiri dari tiga unsur yaitu substansi hukum, struktur hukum dan budaya hukum. ${ }^{8}$ Struktur hukum yaitu faktor yang struktural atau bisa dikatakan dalam suatu sistem ada organ yang bergerak untuk membuat suatu peraturan maupun melaksanakan putusan. ${ }^{9}$ Aspek struktur hukum ini berkaitan dengan tidak adanya lembaga yang mengawasi jalannya pemberian nafkah oleh pihak mantan suami kepada mantan istri sehingga

8 Purba, Imam Pasu Marganda Hadiarto. "Penguatan Budaya Hukum Masyarakat Untuk Menghasilkan Kewarganegaraan Transformatif." Jurnal Civics: Media Kajian Kewarganegaraan 14, No. 2 (2017): 146-153.

9 Usman, Atang Hermawan, “Kesadaran Hukum Masyarakat dan Pemerintah Sebagai Faktor Tegaknya Negara Hukum Di Indonesia." Jurnal Wawasan Yuridika 30, No. 1 (2015): 26-53. DOI: http://dx.doi.org/10.25072/jwy.v30i1.74. 
menimbulkan tindakan lalai dari pihak mantan suami karena tidak adanya pengawasan yang tegas dan jelas terhadap eksekusi dari putusan pengadilan pasca diputus cerai. Selanjutnya substansi hukum merupakan hasil ciptaan dari struktur hukum yang diwujudkan dalam bentuk perundang-undangan. Peraturan perundangundangan untuk menjamin mantan suami memberikan nafkah untuk mantan istri telah dirumuskan dalam ketentuan UU Perkawinan, PP No. 10/1983, HIR dan PP No. 9/1975 namun tidak menjadikan mantan suami untuk mentaati dan melaksanakan ketentuan dari rumusan perundang-undangan tersebut untuk bertanggung jawab memberikan nafkah setelah diputus cerai oleh pengadilan. Kemudian budaya hukum yang merupakan pemikiran, nilai serta harapan terhadap kaidah atau norma dalam kehidupan sosial masyarakat.

Kesadaran hukum dari suatu masyarakat merupakan perwujudan dari budaya hukum yang seharusnya selalu ditanamkan supaya tingkat kepatuhan hukum masyarakat semakin tinggi. ${ }^{10}$ Sebenarnya kesadaran hukum merupakan kesadaran akan nilai-nilai yang terdapat di dalam diri manusia tentang hukum yang ada atau tentang hukum yang diharapkan ada. ${ }^{11}$ Kesadaran hukum masyarakat dalam hal ini berkaitan dengan kesadaran dari pihak mantan suami untuk bertanggung jawab memberikan nafkah kepada mantan istri setelah diputus cerai belum terwujud sehingga kesadaran tersebut perlu ditanamkan agar tidak lalai dalam melaksanakan kewajibannya. Ketiga aspek yang ada dalam sistem ini sangat menentukan tercapainya tujuan hukum yang bisa bermanfaat bagi kehidupan masyarakat. Satu saja aspek tidak terpenuhi maka tujuan hukum tidak akan dapat terwujud dalam hal ini struktur hukum yakni instansi yang seharusnya ada untuk mengawasi jalannya mantan suami memberi nafkah kepada mantan istri. Tidak adanya pengawasan dari instansi terkait mengakibatkan Mantan suami melalaikan kewajiban yang seharusnya menjadi tanggung jawabnya. Hal ini sangat merugikan para istri yang telah dicerai oleh suaminya karena menanggung beban untuk menghidupi anak sendirian. Selain itu tidak adanya regulasi yang mengatur dengan tegas untuk mengawasi suami yang sudah bercerai memberikan nafkah ke mantan istri sehingga menimbulkan ketidakpastian hukum. ${ }^{12}$ Sehingga mengakibatkan mantan suami menjadi lalai bahkan sering mengabaikan kewajiban terhadap mantan istrinya.

\subsection{Akibat Yang Ditimbulkan Dengan Tidak Adanya Instansi Yang Bertugas Untuk Mengawasi Pemberian Biaya Penghidupan Kepada Mantan Istri Oleh Mantan Suami Setelah Diputus Cerai}

Kelalaian yang dilakukan oleh mantan suami untuk tidak memberikan nafkah kepada mantan istri menimbulkan kerugian bagi mantan istri dan tentunya hal ini mencerminkan adanya ketidakpastian hukum. Ketidakpastian hukum ini terjadi diakibatkan oleh tidak adanya peraturan yang jelas serta tegas untuk mengawasi mantan suami memberikan nafkah kepada mantan istri setelah bercerai. Ketidakpastian hukum ini mencerminkan bahwa tidak tepenuhinya tiga tujuan hukum sebagaimana yang diutarakan oleh Gustav Radbruch yaitu mengenai tiga nilai dasar

10 Rosana, Ellya. "Kepatuhan Hukum Sebagai Wujud Kesadaran Hukum Masyarakat." Jurnal Tapis: Jurnal Teropong Aspirasi Politik Islam 10, No. 1 (2014): 61-84. DOI: https://doi.org/10.24042/tps.v10i1.1600.

11 Hartanto, Wenda. "Kesadaran Hukum Sebagai Aspek Dasar Politik Hukum Legislasi: Suatu Tinjauan Filsafat." Jurnal Rechts Vinding: Media Pembinaan Hukum Nasional 4, No. 3 (2015): 469-483.

12 Ibid. 
hukum, meliputi; keadilan (filosofis), kepastian hukum (juridis) dan kemaanfaatan bagi masyarakat (sosiologis). ${ }^{13}$ Sebagai pengemban nilai keadilan hukum akan selalu menjadi pedoman agar selalu bisa menilai suatu aturan hukum yang berlaku itu adil atau tidak. ${ }^{14}$

Pada aspek keadilan menunjuk adanya persamaan hak didepan hukum. Kesamaan dihadapan hukum ini telah tercermin dari adanya persamaan dimuka hukum antara pihak mantan suami dan pihak mantan istri yang kedudukannya sama dihadapan sidang pengadilan tanpa membedakan jenis kelamin, status sosial dan kedudukan ekonomi. Walaupun dalam Pasal 31 ayat (3) UU Perkawinan menentukan kedudukan suami harus menjadi kepala keluarga serta istri harus menjadi IRT tetapi pada sidang pengadilan kedudukan baik pihak suami serta istri sama dihadapan hukum sesuai dengan prinsip persamaan didepan hukum yang dianut sebagaimana Pasal 27 ayat (1) UUD 1945 yang menentukan, setiap warga negara mempunyai derajat yang setara didalam hukum serta bersamaan juga didalam pemerintahan maka daripada itu wajib menjunjung tinggi hukum serta pemerintahan tersebut tanpa terkecuali. Kemudian aspek manfaat menunjuk pada tujuan keadilan tersebut yaitu agar bermanfaat bagi kehidupan manusia, aspek ini juga yang akan menentukan dan menjadi isi dari suatu hukum. ${ }^{15}$

Dalam aspek manfaat ini belum adanya tujuan keadilan yang seharusnya memberikan manfaat baik bagi pihak mantan istri maupun mantan suami karena setelah diputusnya perceraian oleh pengadilan sebagian besar pihak mantan suami tidak menjalankan amanat hasil sidang putusan cerai tersebut untuk memberikan nafkah kepada mantan istri serta anak-anak dari hasil perkawinanya yang mengakibatkan timbulnya kerugian materiil bagi pihak mantan istri. Sehingga dari aspek manfaat hukum yang belum terpenuhi ini sangat mempengaruhi juga aspek kepastian hukum yang seharusnya didapatkan kedua belah pihak secara adil yang bertujuan untuk meningkatkan kebaikan yang terdapat pada hidup manusia betulbetul sudah berfungsi sebagaimana peraturan yang telah dipatuhi. ${ }^{16}$

Norma-norma yang bertujuan untuk memajukan kebaikan dalam kehidupan manusia belum sepenuhnya berfungsi, dikarenakan tidak adanya kejelasan norma untuk mengawasi pelaksanaan mantan suami memberikan nafkah kepada mantan istri setelah diputus cerai oleh pengadilan. Hal ini menimbulkan rasa ketidakadilan bagi mantan istri yang seharusnya berhak untuk mendapatkan nafkah guna memenuhi kebutuhan hidupnya berserta kehidupan anaknya setelah bercerai namun masih harus berjuang agar mantan suaminya melaksanakan kewajibannya tersebut. Keterkaitan antara aspek kepastian hukum yang akan menciptakan keadilan kemudian memberikan manfaat hukum saling terhubung antar satu dan lainnya sehingga tercapainya suatu tujuan hukum. Hal ini menjadi indikator bahwa sudah bekerja atau tidaknya hukum dalam suatu masyarakat dan sudah tercapai atau belumnya tujuan hukum tersebut.

13 Muslih, Muhammad. “Negara Hukum Indonesia Dalam Perspektif Teori Hukum Gustav Radbruch (Tiga Nilai Dasar Hukum)." Legalitas: Jurnal Hukum 4, No. 1 (2017): 130-152. DOI: http://dx.doi.org/10.33087/legalitas.v4i1.117.

14 Fauzi, M. "Menimbang Konstruksi Hukum Kepailitan Bank; Perspektif Nilai-Nilai Dasar Dan Tujuan Hukum." Risalah Hukum 6, No. 1 (2010): 1-8.

15 Dwisvimiar, Inge. "Keadilan Dalam Perspektif Filsafat Ilmu Hukum." Jurnal Dinamika Hukum 11, No. 3 (2011):522-531. DOI: http://dx.doi.org/10.20884/1.jdh.2011.11.3.179.

16 Nuryanto, Carto. Penegakan Hukum Oleh Hakim Dalam Putusan Antara Kepastian Hukum Dan Keadilan. Jurnal Hukum Khaira Ummah 13, No. 1 (2018): 71-84. 
Dari ketiga aspek tujuan hukum yang belum terpenuhi sebagaimana telah dijelaskan tersebut terlihat bahwa akibat yang dtimbulkan dari tidak adanya instansi yang berhak mengawasi pemberian nafkah oleh mantan suami kepada mantan istri yaitu suami tidak melaksanakan kewajiban sebagaimana yang telah dibebankan kepadanya berdasarkan putusan pengadilan yang mengakibatkan mantan istri harus berjuang untuk memenuhi kebutuhan hidupnya serta anak dari hasil perkawinannya. Ketidakberdayaan mantan istri untuk menuntut nakfah kepada mantan suaminya ini juga disebabkan tidak adanya instansi yang mengawasi pelaksanaan pemberian nafkah oleh mantan suami. Namun apabila mantan suami tidak memberikan nafkah kepada mantan istrinya serta anaknya sebagaimana telah diputus di pengadilan, maka pihak yang dirugikan dalam hal ini mantan istri berhak untuk mengajukan gugatan perdata ke pengadilan untuk menuntut hak-hak keperdataan anak yang diabaikan. ${ }^{17}$

Tidak tercapainya tujuan hukum ini mengindikasikan tidak adanya perlindungan hukum bagi mantan istri yang telah bercerai. Perlindungan hukum sangat erat kaitannya dengan aspek keadilan. ${ }^{18}$ Perlindungan hukum dibedakan menjadi dua macam, yaitu perlindungan hukum preventif dan perlindungan hukum represif. Perlindungan hukum preventif merupakan perlindungan hukum yang mengarah pada tindakan yang bersifat pencegahan. ${ }^{19}$ Belum adanya kepastian hukum mengenai adanya instansi yang mengawasi pelaksanaan pemberian nafkah dari mantan suami kepada mantan istri mengindikasikan belum adanya perlindungan hukum preventif atau pencegahan kepada mantan istri sehingga mantan suami bisa melalaikan tanggung jawabnya untuk menafkahi mantan istri setelah diputus cerai pengadilan. Perlindungan hukum represif yaitu perlindungan hukum yang dilakukan untuk menyelesaikan atau menanggulangi suatu peristiwa atau kejadian yang telah terjadi. ${ }^{20}$ Perlindungan hukum represif yang diberikan terkait dengan belum adanya instansi yang melakukan pengawasan kepada mantan suami untuk memberikan nafkah kepada mantan istri yaitu mantan istri dapat mengajukan gugatan perdata kepada pengadilan karena merasa dirugikan akibat tidak terpenuhinya nafkah yang seharusnya menjadi tanggung jawab dari mantan suami.

\section{Kesimpulan}

Tidak adanya pengaturan yang mengatur secara tegas untuk mengawasi mantan suami memberikan nafkah kepada mantan istri setelah diputus cerai menjadikan mantan suami bersikap lalai bahkan mengabaikan putusan pengadilan untuk melaksanakan kewajibannya. Kelalaian mantan suami untuk melaksanakan tanggung jawabnya menunjukan bahwa tidak terlaksananya tujuan hukum yakni dari aspek manfaat serta kepastian hukum. Pada aspek manfaat ini belum menunjukan adanya tujuan keadilan bagi mantan istri yang merasa dirugikan akibat tidak terpenuhinya nafkah dari mantan suami untuk memenuhi kehidupannya serta kebutuhan anak dari hasil perkawinan setelah bercerai. Pada aspek kepastian hukum belum adanya norma-

17 Rifqi, M. "Pemenuhan Hak Istri Dan Anak Akibat Putusnya Perkawinan Karena Perceraian (Studi Kasusu Di Pengadilan Agama Banjarmasin)." Jurnal Pendidikan Kewarganegaraan 4, No. 7 (2014): 558-564. DOI: http://dx.doi.org/10.20527/kewarganegaraan.v4i7.440.

18 Rachmadini, Vidya Noor, "Perlindungan Hukum Bagi Investor Dalam Pasar Modal Menurut Undang-Undang Pasar Modal Dan Undang-Undang Otoritas Jasa Keuangan." Pena Justisia 18, No. 1 (2019): 89-96. DOI: http:// dx.doi.org/10.31941/pj.v18i2.1093.

19 Mahamit, Jisia, "Perlindungan Hukum Atas Merek Dalam Perdagangan Barang Dan Jasa." Lev Privatum 1, No. 3 (2013): 90-100.

20 Ibid. 
norma untuk mengawasi pelaksanaan mantan suami memberikan nafkah kepada mantan istrinya setelah diputus cerai oleh pengadilan. Serta tidak adanya perlindungan hukum prenventif yakni belum adanya instansi yang mengawasi jalannya pemberian nafkah mantan suami mengakibatkan mantan suami lalai dalam memenuhi tanggung jawabnya untuk menafkahi mantan istri beserta anaknya.

\section{DAFTAR PUSTAKA}

\section{Buku:}

Diantha, I Made Pasek. Metodologi Penelitian Hukum Normatif Dalam Justifikasi Teori Hukum. Cet. II. (Jakarta, Prenadamedia Group, 2012).

Zainuddin \& Zainuddin, Afwan. Kepastian Hukum Perkawinan Siri dan Permasalahannya Ditinjau dari Undang-Undang Nomor 1 Tahun 1974. Cet. I. (Yogyakarta, Deepublish, 2017).

\section{Jurnal:}

Dewantara, Julian Robert, Sarjana, I Made, dan Darmadha, I Nyoman, “ Akibat Hukum Pembatalan Hibah Istri Terhadap Suami Setelah Adanya Perceraian (Analisis Kasus: Putusan Mahakamah Agung Nomor 1893 K/Pdt/2015)" Kertha Semaya: Journal Ilmu Hukum 7 No.5 (2019): 1-13.

Dwisvimiar, Inge. "Keadilan Dalam Perspektif Filsafat Ilmu Hukum." Jurnal Dinamika Hukum 11, No. 3 (2011): 522-531. DOI: http://dx.doi.org/10.20884/1.jdh.2011.11.3.179.

Erwinsyahbhana, Tengku. "Sistem Hukum Perkawinan Pada Negara Hukum Berdasarkan Pancasila." Jurnal Ilmu Hukum 3, No. 1 (2012): 1-29. DOI: http://dx.doi.org/10.30652/jih.v3i01.1027.

Fauzi, M. "Menimbang Konstruksi Hukum Kepailitan Bank; Perspektif Nilai-Nilai Dasar Dan Tujuan Hukum." Risalah Hukum 6, No. 1 (2010): 1-8.

Hartanto, Wenda. "Kesadaran Hukum Sebagai Aspek Dasar Politik Hukum Legislasi: Suatu Tinjauan Filsafat." Jurnal Rechts Vinding: Media Pembinaan Hukum Nasional 4, No. 3 (2015): 469-483.

Karirarta, Brody Made dan Purwanto, I Wayan Novy, “Analisis Yuridis Terhadap Pendamaian Dalam Perkara Perceraian Aparatur Sipil Negara Dengan Pendekatan Hukum Perkawinan", Kertha Semaya: Journal Ilmu Hukum 5 No. 1 (2017), 1-17.

Mahamit, Jisia, "Perlindungan Hukum Atas Merek Dalam Perdagangan Barang Dan Jasa." Lev Privatum 1, No. 3 (2013): 90-100.

Muslih, Muhammad. "Negara Hukum Indonesia Dalam Perspektif Teori Hukum Gustav Radbruch (Tiga Nilai Dasar Hukum)." Legalitas: Jurnal Hukum 4, No. 1 (2017): 130-152. DOI: http://dx.doi.org/10.33087/legalitas.v4i1.117.

Nuryanto, Carto. "Penegakan Hukum Oleh Hakim Dalam Putusan Antara Kepastian Hukum Dan Keadilan." Jurnal Hukum Khaira Ummah 13, No. 1 (2018): 71-84.

Purba, Imam Pasu Marganda Hadiarto. "Penguatan Budaya Hukum Masyarakat Untuk Menghasilkan Kewarganegaraan Transformatif." Jurnal Civics: Media Kajian Kewarganegaraan 14, No. 2 (2017): 146-153.

Rachmadini, Vidya Noor, "Perlindungan Hukum Bagi Investor Dalam Pasar Modal Menurut Undang-Undang Pasar Modal Dan Undang-Undang Otoritas Jasa Keuangan." Pena Justisia 18, No. 1 (2019): 89-96. DOI: http://dx.doi.org/10.31941/pj.v18i2.1093. 
Rais, Isnawati, “Tingginya Angka Cerai Gugat (Khulu') Di Indonesia: Analisis Kritis Terhadap Penyebab dan Alternatif Solusi Mengatasinya." Al-'Adalah 12, No. 1 (2014): 191-204. DOI: https:// doi.org/10.24042/adalah.v12i1.183.

Rifqi, M. "Pemenuhan Hak Istri Dan Anak Akibat Putusnya Perkawinan Karena Perceraian (Studi Kasusu Di Pengadilan Agama Banjarmasin)." Jurnal Pendidikan $\begin{array}{llllll}\text { Kewarganegaraan } 4, \quad \text { No. } 72014): & \text { 558-564. }\end{array}$ http://dx.doi.org/10.20527/kewarganegaraan.v4i7.440.

Rosana, Ellya. "Kepatuhan Hukum Sebagai Wujud Kesadaran Hukum Masyarakat." Jurnal Tapis: Jurnal Teropong Aspirasi Politik Islam 10, No. 1 (2014): 61-84. DOI: https://doi.org/10.24042/tps.v10i1.1600.

Santoso, "Hakekat Perkawinan Menurut Undang-Undang Perkawinan, Hukum Islam Dan Hukum Adat." Yudisia: Jurnal Pemikiran Hukum Dan Hukum Islam 7, No. 2 (2016): 412-434. DOI: http://dx.doi.org/10.21043/yudisia.v7i2.2162.

Sarianti, Betra. "Tingkat Kepatuhan Ayah Membayar Nafkah Anak Pasca Perceraian." Supremasi Hukum: Jurnal Penelitian Hukum 27, No. 2 (2018): 105-117. DOI: https://doi.org/10.33369/jsh.27.2.105-117

Usman, Atang Hermawan, "Kesadaran Hukum Masyarakat dan Pemerintah Sebagai Faktor Tegaknya Negara Hukum Di Indonesia." Jurnal Wawasan Yuridika 30, No. 1 (2015): 26-53. DOI: http://dx.doi.org/10.25072/jwy.v30i1.74

\section{Tesis:}

Yunani, Elti. Pelaksanaan Pembagian Harta Bersama (Gono Gini) Dalam Praktek Di Pengadilan Agama Bandar Lampung. Tesis. Pada Fakultas Hukum Universitas Diponegoro, 2009.

\section{Peraturan Perundang-Undangan:}

Undang-Undang Dasar Negara Republik Indonesia Tahun 1945.

Undang-Undang Nomor 16 Tahun 2019 Tentang Perubahan Atas Undang-Undang Nomor 1 Tahun 1974 Tentang Perkawinan, Lembaran Negara Republik Indonesia Tahun 2019 Nomor 186, Tambahan Lembaran Negara Republik Indonesia Nomor 6401.

Peraturan Pemerintah Nomor 9 Tahun 1975 Tentang Pelaksanaan Undang-Undang Nomor 1 Tahun 1974 Tentang Perkawinan, Lembaran Negara Republik Indonesia Tahun 1975 Nomor 12, Tambahan Lembaran Negara Republik Indonesia Nomor 3050.

Peraturan Pemerintah Nomor 10 Tahun 1983 Tentang Izin Perkawinan dan Perceraian Bagi Pegawai Negeri Sipil, Lembaran Negara Republik Indonesia Tahun 1983 Nomor 13, Tambahan Lembaran Negara Republik Indonesia Nomor 3250.

Kompilasi Hukum Islam.

Herzien Inlandsch Reglement. 